\title{
Influence of Human Resource Management Practices on Competitive Advantage through Operational Excellence in SME Food and beverage in Banjar City West Java
}

\author{
Andri Irawan', Syamsul Hadi Senen², Asep Kurniawan ${ }^{3}$ \\ \{andriirawan@upi.edu ${ }^{1}$, eshasenen@upi.edu ${ }^{2}$, asep.kurniawan@lecture.unjani.ac.id ${ }^{3}$ \} \\ ${ }^{1,2}$ Universitas Pendidikan Indonesia, Jl. Dr. Setiabudi No. 229 Bandung 40154 Indonesia \\ ${ }^{3}$ Universitas Jenderal Achmad Yani, Jl. Terusan Jenderal Sudirman Cimahi, Jawa Barat Indonesia Telp. \\ 6656611, Indonesia
}

\begin{abstract}
The competitive advantage for SMES has become a necessity in facing increasingly stringent competition. One of them is in the food and beverage sector in Banjar City. One of the causes that influence competitive advantage is the practice of human resource management and operational excellence. The type of research conducted is causal research, the population in this research is the perpetrators of food and beverage SMES while samples were taken as many as 50 respondents with sampling techniques using the sample considerations. The analysis tool used is SEM Pls. The average rate of respondent perception response to human resource management practices, operational excellence and competitive advantage belongs to the very high category. While the analysis results show that human resource management practices do not directly influence the competitive advantage but the practice of human resource management will influence the competitive advantage Supported by operational Excellence.
\end{abstract}

Key words: Human resource management practices, operational excellence, competitive advantage

\section{Introduction}

Banjar City is a land area with an area of $131.97 \mathrm{~km} 2$ and is at an altitude of between 20 and 500 meters above sea level (MDPL) and tropical climates. Most of the area of Banjar city is at an altitude of less than 100 MASL which reaches 87.10 percent and the remaining 12.90 percent is at the altitude of 100-500 masl. Banjar Region, formerly the status of Administrative city under Ciamis Regency, was formed into new autonomy in the year 2003. Currently the area of Banjar city includes 16 villages, 9 Kelurahan, 103 Dusun, 297 RW and 1,146 RT divided into 4 sub-districts of Purwaharja sub-district in the north, Banjar Subdistrict in the west, Pataruman subdistrict in the south and Langensari Sub-district to the east. [1].

The high rate of population growth in Purwaharja subdistrict is more influenced by the magnitude of migrations that enter the region. Not to be denied the rapid economic growth of the sub-districts in Banjar city since 2010-2017 has become a magnet for residents from other regions to live. Based on the comparison according to the four main sectors in Banjar city in 2017 it is seen that the choice of working in the service sector dominates the working market in Banjar City of 29,726 people followed by the trade sector as many as 27,415 people, then in Industry sector as much as 15,730 people, then the smallest in agriculture sector as much 
as 11,161 people. The labour market of Banjar city is also characterized by the high number of employment opportunities (TKK). This can be seen at the high percentage of the population of labour force working whose magnitude reaches 94 percent in the year 2017. [1].

The development of small business in Banjar city is very rapidly at this time which is $46.67 \%$ with labor absorption of $20.31 \%$. The majority of small businesses in Banjar City are small food businesses that utilize agricultural products such as bananas, soybeans and other. [1]. It is also supported by the average expenditure per capita consumption on three production groups based on the criteria of the world Bank, which is $40 \%$ of the population with low expenditures proportioning its spending on food and beverages by $29.36 \%$ from $100 \%$ of the total food commodity, $40 \%$ of the population with expenditure is proportioning its spending on food and beverages as high as $32.10 \%$ of the total food commodity $100 \%$ and $20 \%$ of the population with higher expenditure is proportionated Its spending on food and beverages is $39.18 \%$ of the total $100 \%$ of all food commodities. [2]. Based on this, it can be concluded that food and beverage commodity in Banjar City has the largest proportion in the three expenditure groups.

The existence of SMES is very important in an economy so that SMES should get the attention and encouragement to develop better because the SME contributes to the development of local economy, the creation of employment, this will lower the crime rate and unemployment. One of the problems in SMES is the shortage of skilled workers. [3] It is also supported by [4] Quoting about the The EFQM (The European Foundation of Quality Management) where one of its fundamental aspects is the success of an organization based on the ability to manage people who have talents or talents.

[5] In his research on operational excellence in SME Food and beverage in Bandung District concluded that the leadership has an influence of 0.265 or directly $26.5 \%$ and the environmental excellence effect of 0.230 or $23 \%$ partially While simultaneously amounting to 0.142 or $14.2 \%$ of operational excellence. Operational excellence is an implementation of a consistent and reliable business strategy in a competition or competition. [6].

HRM is a critical asset of the organization that is not only included in the company's philosophy but also in the strategic planning process. Human resources need to be well managed because it has a prositive impact on the company, if human resources are well managed by the company will have a positive impact on innovative work behavior. Further innovative treatment of work will have a positive impact on the company's innovations [7].

Aspects of competitive advantage is a necessity for a business organization in winning competition, [8] In his research on SMES in Malaysia concluded that in order to achieve a competitive advantage in SMES needed the right technological innovations in addition [8] also have a knowledge management factor in creating a competitive advantage. Based on the above, the central issue in this research is the influence of human resource management practices on competitive advantage through operational excellence in SME Food and beverage in Banjar City West Java.

\section{Literature Review}

\subsection{Human resource management practices}

In this era of Revolution 4.0, aspects of human resource management have shifted and become increasingly realized as one of the important aspects and a source of competing excellence. The change in business environment has brought a little impact to the company. [9] In his research concluded that the most important factor in human resource practice is the 
sociocultural and institutional factors. While [10] stated in his research that the implementation of human resources policy for intermediate marketing managers is in the selection, training, appraisal and compensation aspects greatly varies in a company implementing strategy Marketing and business strategies that are aligned or not.

[11] In his research concluded that an entrepreneurial orientation radiated the relationship between strategic human resource management and corporate performance (both financial performance and employee performance). [12] $\mathrm{n}$ his research stated that recent studies have shown that high-performance business organizations practice strategic human Resource Management (SHRM).

\subsection{Competitive Advantage}

The company in running its business strives to form a competitive advantage in winning competition. [13] stated in his research that there was a significant amount of controversy over the comparative model of excellence and its application to international business, particularly as a guide to the success of the country and/or company in the international market. [14] ound that the dimensions of social practice, economics and formal sustainability have a positive effect on the competitive edge, mediated by the company's reputation, customer satisfaction and organizational commitment. Researchers have also found a competitive advantage as a second stage mediator that contributes positively to financial performance.

[15] In his studies using evidence-based approaches to examine the factors that determine the competitive advantage of the dairy supply chain using evidence from the Chinese dairy industry. [8] In his research concluded that knowledge management has a positive and significant relationship directly with technological innovation and competitive advantage; While technological innovations positively and significantly affect competitive advantage. Most remarkable, the role of technological innovation mediation that connects knowledge management and competitive advantage has proven to be positive and significant.

\subsection{Operational Excellence}

Excellence is a term/concept widely used in research and practice. However, while there are many suggested definitions of excellence and success factors behind excellence, some organizations have been able to achieve the goal of excellence. Excellence is defined as a combination of operational excellence (efficiency) and service Excellence (effectiveness). Further analysis guarantees that the existing business advantage model can harm maintaining excellence and make good business. More specifically, the business advantage model seems to overemphasize the creation of value while less stressed how to capture this value. In addition, they often lack strategic components, including concepts such as strategic options, alignment, and sustainable competitive advantage. It has great implications for research and practice. [16]

[17] Concluded in his research in Jordania that operational excellence is simultaneously influenced by the operation strategy, leadership and practice of human resource management, where the operating strategy has the highest influence and Leadership gives the lowest influence. Operational Excellence According to [18] Is a consequence of the company's practice broadly based on the correct principles that can be classified in four dimensions; Progress, corporate alignment and results. To achieve operational excellence, organisations must achieve a high level of maturity and measurable success in four dimensions externally assessed by accredited agencies or consultants. [19] In his research concluded that the 
contortions of operational excellence among all definitions as well as indicators were continuous improvement, cost reduction, quality, time utilization, operational efficiency, staff involvement and optimization of output.

\section{Research Methodology}

The goal that is to be achieved in this research is to measure and know how much the influence of human resource management practices to competitive advantage through operational excellence in SME Food and beverage in Banjar City type Research is causal. The population in this research is the all-perpetrators of food and beverage SMES in Banjar City. Sampling is a selection process against a number of adequate elements of the population. In order for the sample to be generalized to the population, the sample withdrawal technique is not randomly generated so that each member of the population has no equal opportunity to be selected into a sample. The method of sampling carried out by randomly generated sample withdrawal is a non probability sampling of the selected samples that meet the criteria of the researcher (purposive sampling). Purposive sampling is part of a sampling judgement which for the sampling is based on subjective considerations according to some criteria set by researchers based on their knowledge and experience. The number of samples set in this study was 50 respondents of SME actors food and drink in Banjar city. The analysis tool used in this research is SEM Pls. In SEM Pls analysis using two types of evaluation is.

\subsection{Evaluation of the Outer reflective Model}

The evaluation of the outer model aims to evaluate indicator variables. The latent variable measuring model in SEM Pls there are two reflective models and formative models. The evaluation of reflective models consists of:

1. Indicator reliability. Based on the outer loading, if the outer loading value is higher than 0.7 then the indicator variables need to be retained for the theory test, while for exploration testing between $0.7-0.5$. And when less than 0.5 the indicator variable should be eliminated.

2. Discriaffinity validity. Using two methods, cross loading variables. The indicator variables against the latent variables must be larger than the other latent variables.

3. Internal consistency. Composite reliability is used to measure internal consistency. Test theory of its value should be greater than 0.5 .

4. Convergent validity. Convergent Variance Extracted (AVE), used to measure Convergent validity. The AVE value must be greater than 0.5 .

\subsection{Evaluation of Inner Model (structural Model)}

1. Significance and magnitude of independent latent variable influence

This test is to find out whether independent latent variables affect the dependent latent variables, through Test T. As well as evaluate each individual variable latent independently by looking at a path of coefficient of path.

2. Coefficient of determination of $\mathrm{R} 2$ 
The coefficient of determination measures how large a variation of the dependent latent variables is described by the independent latent variable.

\section{Results and discussion}

Based on the processing of data that has been carried out the average response of respondents regarding human resource management practices, operational excellence and competitive advantage obtained the following results:

Table 1. The average respondent's response to the practice of human resource management, operational durability and competitive advantage in SMES food and beverage In Banjar City

\begin{tabular}{|c|l|c|c|}
\hline No & \multicolumn{1}{|c|}{ Dimensions } & Score & Category \\
\hline 1 & $\begin{array}{l}\text { Human Resource Management } \\
\text { Practice }\end{array}$ & 4,74 & Very High \\
\hline 2 & Operational Excellence & 4,90 & Very High \\
\hline 3 & Competitive Advantage & 4,87 & Very High \\
\hline
\end{tabular}

Source : Data processed, 2019

Subsequent researchers conducted a validity test of the instrument of research using SEM Pls, as for the results of the validity testing of instruments are as follows:

Table 2. Outer Loading

\begin{tabular}{|c|c|c|c|}
\hline & HRM Practice & Operational Excellence & Competitive Advantage \\
\hline HRMP1 & 0,925 & & \\
\hline HRMP2 & 0,821 & 0,893 & \\
\hline OE4 & & 0,837 & \\
\hline OE5 & & 0,752 & \\
\hline OE6 & & 0,713 & 0,838 \\
\hline OE7 & & & 0,841 \\
\hline CA4 & & & 0,828 \\
\hline CA5 & & & \\
\hline CA6 & & & \\
\hline
\end{tabular}

Based on the outer loading value, each dimension has an outer loading value greater than 0.5 meaning that all dimensions can be used to form the outer model of SEM Pls. As for linear value validity can be seen in table 3 below:

Table 3. Discriminant Validity

\begin{tabular}{|l|c|c|c|}
\hline & HRM Practice & $\begin{array}{c}\text { Operational } \\
\text { Excellence }\end{array}$ & $\begin{array}{c}\text { Competitive } \\
\text { Advantage }\end{array}$ \\
\hline $\begin{array}{l}\text { Human Resource Management } \\
\text { Practice }\end{array}$ & 0.875 & & 0.802 \\
\hline Operational Excellence & 0.394 & 0.585 & 0.836 \\
\hline Competitive Advantage & 0.115 & & \\
\hline
\end{tabular}

Source : Data processed, 2019

Based on the value of Forner Larcker the latent variable value is entirely higher compared to other latent variables. So that the model is built qualified from discriaffinity validity. 
Furthermore, researchers conduct instrument testing to determine the reliability. To measure internal consistency use composite reliability values. Here is the composite reliability table.

Table 4 . Composite Reliability

\begin{tabular}{|l|c|}
\hline \multicolumn{1}{|c|}{ Variable } & Cronbach's Alpha \\
\hline Human Resource Management Practice & 0.704 \\
\hline Operational Excellence & 0.844 \\
\hline Competitive Advantage & 0.785 \\
\hline
\end{tabular}

Source : Data processed, 2019

Based on the composite reliablity table, to test the internal consistency, the overall variable has a value of more than 0.6. This means the models that are built are eligible to form a consistent model in measuring covergent validity, used the value of average variance validity. The results are presented in the following table 5.

Table 5. Covergent Validity

\begin{tabular}{|l|l|}
\hline \multicolumn{1}{|c|}{ Variable } & A VE \\
\hline Human Resource Management Practice & 0,765 \\
\hline Operational Excellence & 0.643 \\
\hline Competitive Advantage & 0.698 \\
\hline
\end{tabular}

Based on the table Average Variance Extracted (AVE) indicates that the AVE value above 0.5 means that all outer models for this research are valid so there is no need to dissipation indicators. Further to know the outcome of the influence of human resource management practices on competitive advantage through operational excellence can be seen in the image below: 


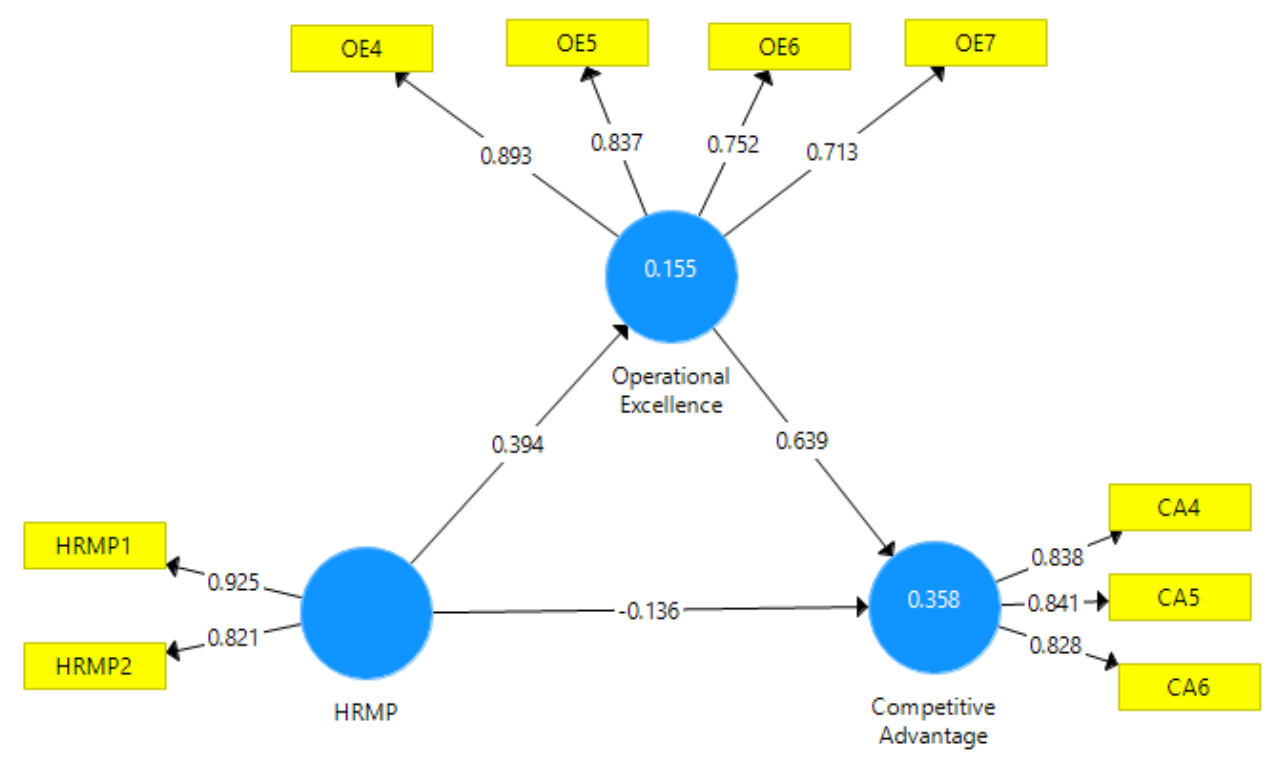

Fig. 1. Influence of Human Resource Management Practices on Competitive Advantage through Operational Excellence in SME Food and Beverage in Banjar City

Based on the image above the correlation coefficient of MSDM's practice variable to operational excellence of 0.394 it shows that the relationship between MSDM's practice of operational excellence belongs to the category enough. While the value of coefficient of correlation between operational excellence to a competitive advantage of 0.639 it shows that the relationship between operational excellence to competitive advantage is included in the strong category. The correlation coefficient value of MSDM's practice of a competitive advantage of- 0.136 indicates that the relationship between MSDM's practice of competitive advantage includes negative and weak categories. Furthermore, the influence of MSDM practice on operational excellence is $15.52 \%$ while the influence of operational excellence on competitive advantage is $40.83 \%$. So the total effect of MSDM's practice on competitive advantage through operational excellence is $56.35 \%$. Furthermore, the influence of MSDM's practice on competitive advantage is $1.85 \%$.

\section{Conclusions}

Based on the results and discussion that has been done, the average response of respondents ' perception of human resource management practices, operational excellence and competitive advantage includes very high categories. While based on the results of calculations using SEM Pls can be concluded that the practice of human resources management does not give direct influence to competitive advantage but the practice of human resources management will Influence on competitive advantage supported by operational excellence in SME Food and beverage in Banjar City West Java 


\section{Reference}

[1] Badan Pusat Statistik Kota Banjar, "Statistik Daerah Kota Banjar 2018," 2018.

[2] Badan Pusat Statistik Kota Banjar, "Statistik Kesejahteraan Rakyat Kota Banjar Tahun $2018, " 2018$.

[3] J. Houghton, "The role of Small and Medium Scale Enterprise in local economic development ( LED ),” J. Bus. Retail Manag. Res., vol. 11, no. 2, pp. 133-139, 2017.

[4] R. M. Shehadeh, M. Maqableh, M. O. Al-zoubi, A. O. Akhorshaideh, and M. K. Alshami, "Review the Operational Excellence Factors of Service Firms: A Literature Review," Eur. J. Bus. Manag., vol. 8, no. 3, pp. 1-11, 2016.

[5] E. Irawan, A. dan Ludiya, "Influence of Leadership and Environmental Excellence SME Towards Operational Excellence In Bandung District," in The 4th International Conference on Information Technology and Bussiness (ICITB), 2018, pp. 1-8.

[6] C. Seifert, Achieving Operational Excellence in the Face of Complexity. London: Wilson Perumal \& Company; Ltd, 2013.

[7] Javed et all, "Ethical leadership, trust in leader and creativity: The mediated mechanism and an interacting effect," J. Manag. Organ., vol. 24, no. 3, pp. 388-405, 2018.

[8] V. H. Lee, A. T. L. Foo, L. Y. Leong, and K. B. Ooi, "Can competitive advantage be achieved through knowledge management? A case study on SMEs," Expert Syst. Appl., vol. 65, pp. 136-151, 2016.

[9] A. Al Ariss and Y. Sidani, "Comparative international human resource management: Future research directions," Hum. Resour. Manag. Rev., vol. 26, no. 4, pp. 352-358, 2016.

[10] E. M. Olson, S. F. Slater, G. T. M. Hult, and K. M. Olson, "The application of human resource management policies within the marketing organization: The impact on business and marketing strategy implementation," Ind. Mark. Manag., vol. 69, no. xxxx, pp. 62-73, 2018.

[11] C. Zehir, Y. Gurol, T. Karaboga, and M. Kole, "Strategic Human Resource Management and Firm Performance: The Mediating Role of Entrepreneurial Orientation,” Procedia - Soc. Behav. Sci., vol. 235, no. October, pp. 372-381, 2016.

[12] A. Allui and J. Sahni, "Strategic Human Resource Management in Higher Education Institutions: Empirical Evidence from Saudi,” Procedia - Soc. Behav. Sci., vol. 235, no. October, pp. 361-371, 2016.

[13] S. Dev Gupta, "Comparative Advantage and Competitive Advantage: An Economics Perspective and a Synthesis,” Athens J. Bus. Econ., vol. 1, no. 1, pp. 9-22, 2014.

[14] S. Cantele and A. Zardini, "Is sustainability a competitive advantage for small businesses? An empirical analysis of possible mediators in the sustainability-financial performance relationship," J. Clean. Prod., vol. 182, pp. 166-176, 2018.

[15] H. Ding, Y. Fu, L. Zheng, and Z. Yan, "Determinants of the competitive advantage of dairy supply chains: Evidence from the Chinese dairy industry," Int. J. Prod. Econ., 2018.

[16] M. Thürer et al., "On the meaning and use of excellence in the operations literature : a systematic review," Total Qual. Manag., vol. 0, no. 0, pp. 1-28, 2018.

[17] R. M. Shehadeh, Z. M. F. Al-Zu'bi, A. B. Abdallah, and M. Maqableh, "Investigating Critical Factors Affecting the Operational Excellence of Service Firms in Jordan," J. Manag. Res., vol. 8, no. 1, p. 157, 2016.

[18] S. J. Rusev and K. Salonitis, "Operational Excellence Assessment Framework for 
Manufacturing Companies, ” Procedia CIRP, vol. 55, pp. 272-277, 2016.

[19] M. H. Muazu and R. Tasmin, "Operational Excellence in Manufacturing, Service and the Oil \& Gas: the Sectorial Definitional Constructs and Risk Management Implication," Traektoriâ Nauk. = Path Sci., vol. 3, no. 9, 2017. 